Research Article

\title{
Ripening Response of Sugarcane Varieties to Chemical Ripeners and Economic Benefits during the Early Period of Harvesting at Wonji-Shoa and Metahara Sugarcane Plantations, Central Rift Valley of Ethiopia
}

\author{
Netsanet Ayele $\mathbb{D}$, ${ }^{1}$ Tamado Tana $\mathbb{D}^{2},{ }^{2}$ Philippus Daniel Riekert Van Heerden $\mathbb{D},{ }^{3,4}$ \\ Kebede W/Tsadik $\left(\mathbb{D},{ }^{5}\right.$ and Yibekal Alemayehu ${ }^{5}{ }^{5}$ \\ ${ }^{1}$ Ethiopian Sugar Corporation, Research Centre, Eastern Showa Zone P.O. Box 15, Wonji, Ethiopia \\ ${ }^{2}$ Department of Crop Production, Faculty of Agriculture, University of Eswatini, P.O.Luyengo, M 205, Kwaluseni, Eswatini \\ ${ }^{3}$ South African Sugarcane Research Institute, Mount Edgecombe, Blackburn 4300, South Africa \\ ${ }^{4}$ Department of Plant and Soil Sciences, University of Pretoria, Pretoria 0028, South Africa \\ ${ }^{5}$ School of Plant Sciences, Haramaya University, P.O. Box 138, Dire Dawa, Ethiopia
}

Correspondence should be addressed to Netsanet Ayele; abnetay@gmail.com

Received 8 December 2020; Revised 13 March 2021; Accepted 21 May 2021; Published 2 June 2021

Academic Editor: Othmane Merah

Copyright $\odot 2021$ Netsanet Ayele et al. This is an open access article distributed under the Creative Commons Attribution License, which permits unrestricted use, distribution, and reproduction in any medium, provided the original work is properly cited.

Wonji-Shoa and Metahara sugarcane plantations experience reduced sucrose content (\%) during the starting period of sugarcane crushing due to the combined influence of high $\left(>27^{\circ} \mathrm{C}\right)$ temperature and the presence of high residual soil moisture. Studies elsewhere showed the potential of chemical ripeners in boosting the sucrose content (\%), where natural ripening is deterred by these challenges. Accordingly, a field experiment was conducted to evaluate the responsiveness of selected sugarcane varieties to chemical ripeners at both plantations. The treatments consisted of a factorial combination of four sugarcane varieties (B52298, NCo334, C86-56, and SP70-1284) and six ripener treatments: (1) Ethephon ${ }^{\mathrm{TM}}\left(720 \mathrm{~g} \mathrm{ai} \mathrm{ha}^{-1}\right)$, (2) Fusilade Forte ${ }^{\mathrm{TMM}}\left(25.6 \mathrm{~g}\right.$ ai ha $\left.^{-1}\right)$, (3)

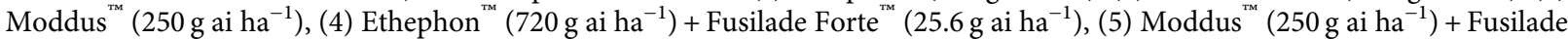
Forte $^{\mathrm{Tm}}\left(25.6 \mathrm{~g} \mathrm{ai} \mathrm{ha}^{-1}\right)$, and (6) Unsprayed (control). The experiment was laid out in a randomised complete block design in a factorial arrangement with three replications. The results showed a significant $(p=0.025)$ and highly significant $(p=0.001)$ variety by ripener interaction in stalk height and sucrose content, respectively, while the main effect ripener highly significantly affected stalk weight $(p=0.001)$ and sucrose yield $(p=0.003)$. The variety C86-56 sprayed with combinations of Ethephon $^{\mathrm{TM}}+$ Fusilade Forte $^{\mathrm{TM}}$ and Moddus $^{\mathrm{TM}}+$ Fusilade Forte $^{\mathrm{Tm}}$ had the shortest stalk heights of 1.27 and $1.29 \mathrm{~m}$, respectively,

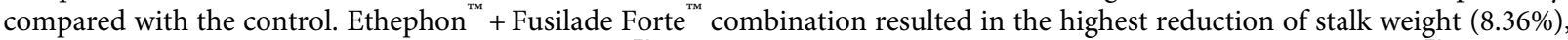
while the lowest was recorded in the sole Moddus ${ }^{\mathrm{TM}}$ treatment $(6.31 \%)$. From the ripener treatments, the Moddus ${ }^{\mathrm{m}}+$ Fusilade Forte $^{\mathrm{Tm}}$ combination and Ethephon $^{\mathrm{TM}}+$ Fusilade Forte $^{\mathrm{TM}}$ combination improved sucrose yield by 1.42 and $1.34 \mathrm{tha}^{-1}$, respectively,

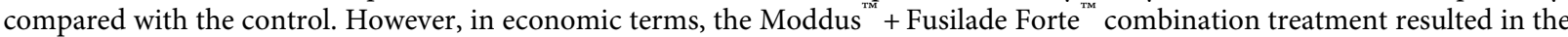
highest marginal rate of return of $1244 \%$. Therefore, the Moddus ${ }^{\mathrm{TM}}+$ Fusilade Forte $^{\mathrm{Tm}}$ combination ripener treatment was found to be promising to be evaluated at a commercial scale on immature sugarcane varieties B52-298, NCo334, and SP70-1284.

\section{Introduction}

Sugarcane (Saccharum spp., hybrid) is cultivated in Ethiopia at a commercial level [1], as well as by smallholder farmers [2]. It also has broad socioeconomic advantages [3]. However, the per-capita sugar consumption of Ethiopia is one of the lowest in the world with about 5 to $6 \mathrm{~kg}$ per annum, and future sugar consumption growth is expected to be around 3-4\% annually, which was forecasted to grow by 0.4 million tons by 2030 [4]. The total annual sugar production in the country was reported to be 400,000 tons in 2018 , which only covers $60 \%$ of the annual demand for 
domestic consumption [5]. The country is endowed with a favourable climate, enormous land, and water resources for large-scale irrigated development of sugarcane [1] with an average sugarcane yield potential of 162 tons per hectare [6]. Nonetheless, the value of sugarcane is determined by the amount of recoverable sucrose per weight of cane [7]. In Ethiopia, sucrose is the main product of sugarcane processing [8], and its quantity principally depends on the quality of sugarcane supplied [9]. This suggests the need for maintaining quality using appropriate ripening management as an indispensable means [10].

Although the dry matter yield potential of sugarcane in the country is high [6], the quantity partitioned to sucrose varies depending upon the variety, age [11], season [8], soil fertility, irrigation [12], weed, pest and disease control [13], and the length of crushing season [7]. Nevertheless, air temperature and soil moisture are the major factors affecting the partitioning of sucrose in sugarcane [14]. At a higher temperature, from the total carbon fixed and stored, sugarcane partitions less carbon to sucrose [15]. The availability of soil moisture also reduces the sucrose content of sugarcane during ripening due to the high growth sink demand [16]. In the ripening phase, there should be a synthesis and rapid accumulation of sucrose with a concomitant reduction of vegetative growth and a decline in the level of monosaccharides (fructose and glucose) in stalks [12].

Wonji-Shoa and Metahara sugarcane plantations have a total area of 10,342 and 10,235 ha, respectively. Conventionally, to maximise the sucrose content (\%) of cane harvested from these plantation areas, harvesting of sugarcane is conducted after drying off the cane by withholding irrigation for a specified period ranging from 5 to 9 weeks before harvesting [17]. However, the sucrose content of cane in the beginning (September to November) period is lower due to the presence of residual soil moisture coupled with the high temperature in July and August, and this has been reported to be a persistent problem at both estates [8]. This indicates the inadequacy of natural ripening [18], which resulted in the need for accurate control over crop water supply [19] and the reduction in cane and sucrose yield from the extreme withholding of water during drier periods [20].

Chemical ripeners have become an important technology to tackle challenges related to low sucrose content in many sugar industries of the world [12]. Ripeners used in sugarcane are plant regulators whose action consists of modification of plant morphology and physiology, which can alter plant production quantitatively and qualitatively [21]. The use of ripeners can provide gains in sucrose quality above those achieved by natural ripening $[12,19]$. Ripeners can reduce plant height, increase sucrose content, advance plant maturation, and increase sucrose yield, and they can also present effects on enzymes that catalyse sucrose accumulation in the internodes [21]. The technology has potentially considerable impact in areas overwhelmed with poor natural ripening conditions [22]. The successful introduction of ripener technology could also facilitate the harvest of cane earlier in the season when it is relatively immature [23].

The chemical ripeners currently in use in many sugar industries include glyphosate (e.g., Roundup ${ }^{\text {TM }}$ ), 2-chloroethylphosphonic acid (e.g., Ethephon ${ }^{\mathrm{Tm}}$ ), fluazifopp-butyl (e.g., Fusilade Forte ${ }^{\mathrm{rm}}$ ), and trinexapac-ethyl (Moddus ${ }^{\mathrm{rm}}$ ) [12]. In terms of their modes of action, glyphosate and fluazifop-p-butyl are herbicidal and suppress new tissue formation at a sublethal dose [24], while 2-chloroethylphosphonic acid and trinexapac-ethyl have a hormonal mode of action $[25,26]$. The hormonal mechanism of improvement in sucrose content through 2-chloroethylphosphonic acid emanates from the active ingredient ethylene $[25,26]$, which reduces the demand for sucrose for vegetative growth [24]; but the mechanism for trinexapacethyl is related to its ability of inhibition of elongation of internode, resulting from the reduction in the level of $\mathrm{GA}_{1}$ [27]. Earlier works also confirmed the efficacy of sole application of glyphosate [24, 28], 2-chloroethylphosphonic acid [29, 30], fluazifop-p-butyl [30, 31], trinexapac-ethyl $[32,33]$, and combination of ripeners $[23,29,30]$ in improving sucrose yield of sugarcane.

However, to effectively use chemical ripeners at a commercial level, it is vital to generate information regarding the response of sugarcane varieties to these chemicals. In line with this study, reports from different sugar industries confirmed the need for evaluation of varieties for their response to chemical ripeners [23, 28]. In this regard, a preliminary study conducted at Metahara sugarcane plantation in the 1980s using fluazifop-p-butyl showed that the sucrose content (\%) of varieties B41-227 and NCo376 were improved by 0.47 and $0.57 \%$ units, respectively, when compared with untreated control plots [29].

Although these studies showed improvement in juice quality of some sugarcane varieties, the emergence of new chemical ripeners, combination treatments, and sugarcane varieties necessitated another study that can provide up-todate information to the estates. Therefore, this study was conducted to evaluate the response of selected sugarcane varieties to chemical ripeners at Wonji-Shoa and Metahara sugarcane plantations.

\section{Materials and Methods}

2.1. Description of the Study Areas. The present investigation was carried out at Wonji-Shoa and Metahara sugarcane plantations from December 2017 to October 2018. WonjiShoa Sugarcane plantation is located in the Rift Valley of Ethiopia $\left(8^{\circ} 31^{\prime} \mathrm{N}\right.$ and $\left.39^{\circ} 12^{\prime} \mathrm{E}\right)$, at an average elevation of 1550 masl. The plantation has a mean maximum and minimum air temperature of 26.9 and $15.3^{\circ} \mathrm{C}$, respectively. Similarly, Metahara sugarcane plantation is located in the Rift Valley of Ethiopia $\left(8^{\circ} 51^{\prime} \mathrm{N}\right.$ and $39^{\circ} 52^{\prime} \mathrm{E}$ ), at an average elevation of 950 masl. The plantation has a mean maximum and minimum air temperature of 32.6 and $17.5^{\circ} \mathrm{C}$, respectively. The soils of the experimental fields of Wonji-Shoa and Metahara were clay ( $>54 \%)$ in texture.

During the study period, Wonji-Shoa and Metahara sugarcane plantations obtained a total rainfall of 859 and $317 \mathrm{~mm}$, respectively. As compared to the long-term annual average, both plantations experienced lower rainfall. Moreover, the distribution was not even at both locations (Figure 1). Maximum rainfall of 267 and $120 \mathrm{~mm}$ were 


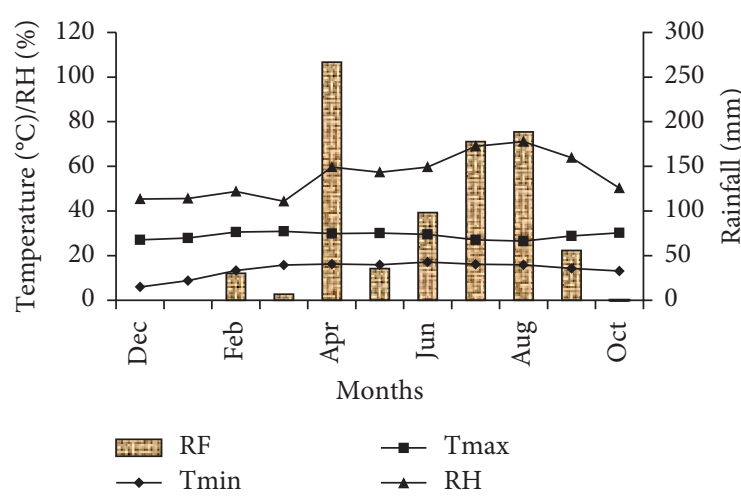

(a)

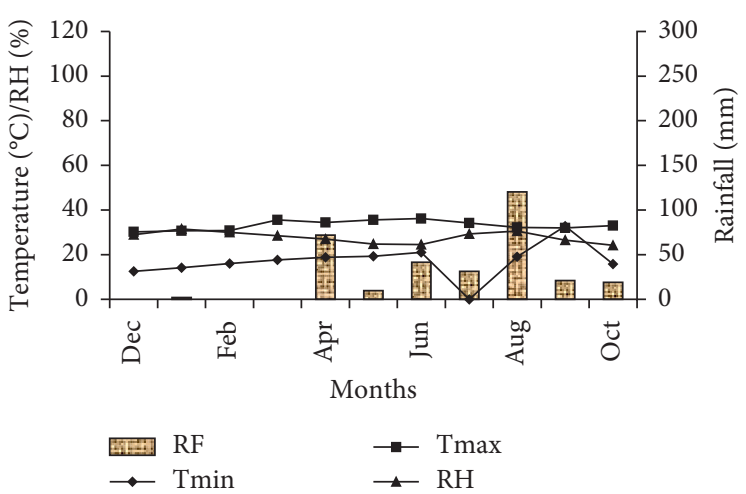

(b)

FIGURE 1: Monthly total rainfall $(\mathrm{mm})$ distribution $(\mathrm{RF})$, relative humidity $(\mathrm{RH})$, and the mean maximum (Tmax) and minimum (Tmin) temperature $\left({ }^{\circ} \mathrm{C}\right.$ ) during the study period at Wonji-Shoa (a) and Metahara (b) sugarcane plantations.

recorded in April and August at Wonji-Shoa and Metahara, respectively. The mean annual minimum temperature recorded at Wonji-Shoa was $13.9^{\circ} \mathrm{C}$ and Metahara was $17.0^{\circ} \mathrm{C}$. The mean annual maximum temperature recorded at Wonji-Shoa was $29.0^{\circ} \mathrm{C}$ and at Metahara was $33.2^{\circ} \mathrm{C}$.

2.2. Description of the Experimental Materials. Two existing sugarcane varieties (B52-298 and NCo334), which have been in cultivation for more than five decades at Wonji-Shoa and Metahara sugarcane plantations, and two new varieties (C86-56 and SP70-1284) recently introduced from Cuba were selected based on their performance at both locations. The chemical ripeners used for the study were 2-chloroethylphosphonic acid (Ethephon ${ }^{\mathrm{TM}}$ ), fluazifop-p-butyl (Fusilade Forte $^{\mathrm{TM}}$ ), and trinexapac-ethyl (Moddus ${ }^{\mathrm{rm}}$ ). The

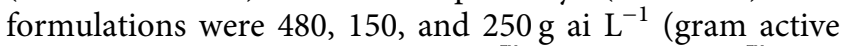
ingredient per litre) for Ethephon ${ }^{\mathrm{TM}}$, Fusilade Forte ${ }^{\mathrm{TM}}$, and Moddus ${ }^{\mathrm{TM}}$, respectively.

2.3. Treatment and Experimental Design. The treatments consisted of a factorial combination of four sugarcane varieties (B52-298, NCo334, C86-56, and SP70-1284) and six ripener treatments: (1) Ethephon ${ }^{\mathrm{TM}}\left(720 \mathrm{~g}^{\text {ai ha }}{ }^{-1}\right)$, (2) Fusilade Forte $^{\mathrm{TM}}\left(25.6 \mathrm{~g}^{\mathrm{ai} \mathrm{ha}}{ }^{-1}\right)$, (3) Moddus ${ }^{\mathrm{M}}\left(250 \mathrm{~g} \mathrm{ai} \mathrm{ha}^{-1}\right)$, (4) Ethephon ${ }^{\mathrm{TM}}\left(720 \mathrm{~g}^{\mathrm{ai} \mathrm{h}} \mathrm{ha}^{-1}\right)+$ Fusilade Forte $^{\mathrm{TM}}(25.6 \mathrm{~g}$ ai $\left.\mathrm{ha}^{-1}\right),(5)$ Moddus $^{\mathrm{TM}}\left(250 \mathrm{~g} \mathrm{ai} \mathrm{ha}^{-1}\right)+$ Fusilade Forte $^{\mathrm{TM}}(25.6 \mathrm{~g}$ ai ha ${ }^{-1}$ ), and (6) Control (unsprayed). The experiment was conducted using a randomised complete block design in a factorial arrangement with three replications.

2.4. Experimental Procedure. The experiment was planted using three budded sets originated from properly managed seed source fields. Throughout the growing period, furrow irrigation was provided until two weeks before harvesting. Urea $(46 \% \mathrm{~N})$ was applied once at $200 \mathrm{~kg} \mathrm{ha}^{-1}$ manually after a mechanical earthing-up operation was conducted at two and a half months of cane age. Weeding was conducted manually as required. Irrigation and weeding were conducted similar to commercial practice on the estates. Field inspections were conducted every 15 days, and there were no diseases and insect pests encountered throughout the growing period.

Each plot had 4 cane rows of 6 meters long and $1.45 \mathrm{~m}$ row spacing with a total plot size of $34.8 \mathrm{~m}^{2}$. Samples were collected from the centre 2 rows. Applications of the ripeners were conducted using a high-clearance boom frame using a motorised power sprayer operating at $100 \mathrm{kPa}$ pressure at an average height of $50 \mathrm{~cm}$ above the canopy with two flood-jet nozzles, used to reduce chemical drift effects, spaced at $50 \mathrm{~cm}$ apart. The spray mixtures were delivered in water volumes of $431 \mathrm{~L} \mathrm{ha}^{-1}$. Spraying was conducted early in the morning when the wind was calm.

The age of harvesting was 10 months at both locations. Ethephon $^{\text {rm }}$, Moddus ${ }^{\text {} м}$, and Fusilade Forte ${ }^{\text {тм }}$ were applied 80, 70 , and 42 days prior to harvesting. For the combination treatment Ethephon $^{\mathrm{TM}}+$ Fusilade Forte $^{{ }^{\mathrm{m}}}$, Ethephon ${ }^{\mathrm{TM}}$ was applied 80 days before harvest followed by Fusilade Forte ${ }^{\text {тм }}$ 42 days before harvesting. Similarly, for the Moddus $^{\mathrm{rm}}+$ Fusilade Forte ${ }^{\mathrm{TM}}$ combination treatment, Moddus $^{\mathrm{TM}}$ was applied 70 days before harvesting followed by Fusilade Forte ${ }^{\mathrm{rm}}$, which was sprayed 42 days before harvesting.

2.5. Data Collection. At harvest, millable stalk height and stalk weight were calculated from 20 stalks, while 10 stalks were used for juice quality viz. Brix (\%) and Pol (\%) measurements. The stalks were randomly selected from the net plot. Millable stalk height was determined by measuring the height of stalks from the ground to the top visible dewlap leaf. Stalk weight was determined using a weighing balance. The number of millable stalks was counted before sampling and harvesting. Cane yield was determined from the net plot area by weighing all stalks using a weighing balance and then converted to tons per hectare.

Brix (\%) was determined by crushing the stalks using a crushing mill, and the juice was analysed in the laboratory using a bench refractometer (Rudolph Research, model J157). Similarly, pol (\%) was determined from the same juice using a saccharimeter (Analytical Autopol 880; Rudolph 
Research). Purity (\%) was calculated as the ratio of pol\%/brix $\%$ and multiplied by 100 . Finally, the sucrose content (\%) was calculated according to the equation described by Berg [30]:

$$
\text { sucrose content }(\%)=[\mathrm{pol} \%-(\text { Brix }- \text { pol } \%) 0.61] 0.75 \text {, }
$$

where 0.61 was the nonsucrose factor and 0.75 was the crop factor. Then, sucrose yield $\left(\mathrm{t} \mathrm{ha}^{-1}\right)$ was determined by multiplying the cane yield ( $\mathrm{t} \mathrm{ha}^{-1}$ ) obtained by the sucrose content (\%) of cane.

2.6. Data Analysis. After verifying the homogeneity of error variances, a combined analysis of variance was done using PROC GLM procedure in SAS, version 9.2 [31]. Comparisons of the treatment means with significant differences for the measured parameters were done using Tukey's studentised range (HSD) test at 5\% level of significance. Normality of the data was assessed using the Kolmogorov-Smirnov test.

The economic feasibility of the ripener treatments was assessed using partial budget analysis following the procedures of CIMMYT [32]. The average experimental sucrose yield results were adjusted downwards by $10 \%$ to reflect the difference between the experimental plot yield and the yield that the sugarcane plantations would expect from the same treatment under their own management [32].

Sales revenue was determined by multiplying the adjusted sucrose yield by the selling price of sucrose in USD (Unite States Dollar). Then, the gross field benefit for each treatment was determined by adding the saving from harvest and transport and sales revenue. Saving from harvest and transport refers to the cost of harvesting and transport saved due to reduction in cane yield by some of the ripener treatments. Thus, savings were determined by multiplying the amount of yield reduced in each ripener treatment and the cost of harvesting and transport. The cost of harvest and transport was fixed at USD 4.5. The variable cost (cost of ripening) includes chemical cost and spraying cost. Cost of chemical ripeners per hectare for Ethephon ${ }^{\mathrm{TM}}$, Fusilade Forte $^{\mathrm{TM}}$, and Moddus ${ }^{\mathrm{TM}}$ were USD 30.00, 23.00, and 33.33, respectively. The cost of spraying per hectare (including the labour cost), which was assumed to be applied using a drone, was estimated to be USD 5.625. Selling price of sugar was taken to be $0.62 \mathrm{USD} \mathrm{kg}^{-1}$.

Net benefit (NB) was calculated by subtracting the total costs that vary (total cost of ripening) from the gross field benefits for each treatment. The marginal rate of return (MRR) was calculated by dividing the difference between the net benefit of the treatment and the control (unsprayed) to variable cost (cost of ripening). For a ripener treatment to be regarded as a worthwhile option to the sugarcane plantations, the minimum marginal rate of return (MRR) was assumed to be $100 \%$ [32]. To check the marginal analysis results, residuals (returns on investment) were calculated for each treatment. The residuals calculated were used to indicate the difference between the net benefits and the cost of the investment.

\section{Results and Discussion}

\subsection{Sugarcane Yield Components}

3.1.1. Stalk Height. The combined analysis over the two locations showed a significant $(p=0.025)$ interaction effect of ripener with variety on stalk height. However, none of the remaining interactions with ripeners were significant (Table 1).

The variety C86-56 treated with combinations of Ethephon $^{\mathrm{TM}}+$ Fusilade Forte $^{\mathrm{TM}}$ and Moddus ${ }^{\mathrm{TM}}+$ Fusilade Forte $^{\mathrm{rm}}$ had the shortest stalk heights of 1.27 and $1.29 \mathrm{~m}$, respectively. In contrast, the longest stalk height $(1.64 \mathrm{~m})$ was recorded in the control (unsprayed) treatment of variety NCo334 (Figure 2). The difference in response among the varieties to chemical ripeners might have been due to their innate genetic differences. In line with this, reports from different sugar industries confirmed the difference in response to chemical ripeners $[27,33]$.

Physiologically, 2-chloroethylphosphonic acid reduces the growth sink demand for sucrose due to the reduction in the lamina size and mass as a result of the release of ethylene [24]. The current research results agree well with previous studies wherein 2-chloroethyl-phosphonic acid did not cause significant stalk height reduction in sugarcane $[19,27]$. According to Rostron [34], a reduction in stalk growth by shortening of one or two internodes may occur, but it was confirmed to be transitory. Contrarily, Abo El-Hamd et al. [35] showed a significant reduction in stalk height due to 2chloroethylphosphonic acid treatment. The reduction in stalk height due to Fusilade Forte ${ }^{\mathrm{TM}}$ treatment was caused by the translocation of the active compound fluazifop-p-butyl to the stalk apical meristem where it terminates stalk growth $[24,34]$ and restricts leaf growth [34]. Abo El-Hamd et al. [35] also reported that fluazifop-p-butyl treatments reduced stalk height independent of the rates considered.

In the same way, the reduction in stalk height due to the treatment with Moddus ${ }^{\mathrm{TM}}$ was caused by the reduction of internode elongation, which resulted from the blockage of gibberellic acid $\mathrm{GA}_{20}$ to $\mathrm{GA}_{1}$ conversion process within the sugarcane stalk [19, 27]. Similarly, van Heerden et al. [19] revealed that trinexapac-ethyl applied at the rate of 200,250, and $500 \mathrm{~g}$ ai ha ${ }^{-1}$ caused a rapid, and near-complete, inhibition of stalk growth up to 56 days after spraying. However, subsequent resumption of growth depended on the application rate.

The stalk height reduction due to treatment with the Ethephon $^{\mathrm{TM}}+$ Fusilade Forte $^{\mathrm{TM}}$ combination treatment (Figure 2) predominately originated from fluazifop-p-butyl contained in Fusilade Forte $[24,34]$. On the other hand, the reduction in stalk height due to treatment with the Moddus $^{\mathrm{TM}}+$ Fusilade Forte ${ }^{\mathrm{TM}}$ combination (Figure 2) could be due to the reduction in stalk elongation from the synergistic effect of both the active ingredients fluazifop-p-butyl and trinexapac-ethyl $[19,24]$.

3.1.2. Stalk Weight. The ripener main effect on stalk weight (Table 1$)$ was highly significant $(p=0.001)$. Fusilade Forte ${ }^{\mathrm{rm}}$, Moddus $^{\mathrm{TM}}$, Moddus ${ }^{\mathrm{TM}}+$ Fusilade Forte ${ }^{\mathrm{TM}}$ combination, and Ethephon $^{\mathrm{TM}}+$ Fusilade Forte $^{\mathrm{TM}}$ combination treatments significantly reduced stalk weight (Figure 3), although actual 
TABLE 1: Combined analysis of variance ( $p$ values) for yield components of sugarcane in a field experiment involving four sugarcane varieties, six chemical ripener treatments, and two locations.

\begin{tabular}{lccc}
\hline Source of variation & $\begin{array}{c}\text { Stalk } \\
\text { height }(\mathrm{m})\end{array}$ & $\begin{array}{c}\text { Stalk weight } \\
\text { (kg stalk-1) }\end{array}$ & $\begin{array}{c}\text { No. of millable } \\
\text { stalks }\left(' 000 \mathrm{ha}^{-1}\right)\end{array}$ \\
\hline Variety $(V)^{1}$ & 0.001 & 0.001 & 0.001 \\
Ripener $(R)^{2}$ & 0.001 & 0.001 & 0.970 \\
Location $(L)^{3}$ & 0.168 & 0.002 & 0.017 \\
$V \times R$ & 0.025 & 0.966 & 0.649 \\
$R \times L$ & 0.653 & 0.802 & 0.891 \\
$V \times R \times L$ & 0.919 & 0.939 & 0.562 \\
\hline
\end{tabular}

${ }^{1}$ Varieties: B52-298, NCo334, C86-56, and SP70-1284; ${ }^{2}$ Ripener treatments: Ethephon ${ }^{\mathrm{Tm}}$, Fusilade Forte ${ }^{\mathrm{Tm}}$, Moddus ${ }^{\mathrm{Tx}}$, Moddus ${ }^{\mathrm{Tx}}+$ Fusilade Forte $^{\mathrm{Tm}}$ combination, Ethephon ${ }^{\mathrm{rx}}+$ Fusilade Forte ${ }^{\text {Tx }}$ combination, and control (unsprayed). ${ }^{3}$ Locations: Wonji-Shoa and Metahara.

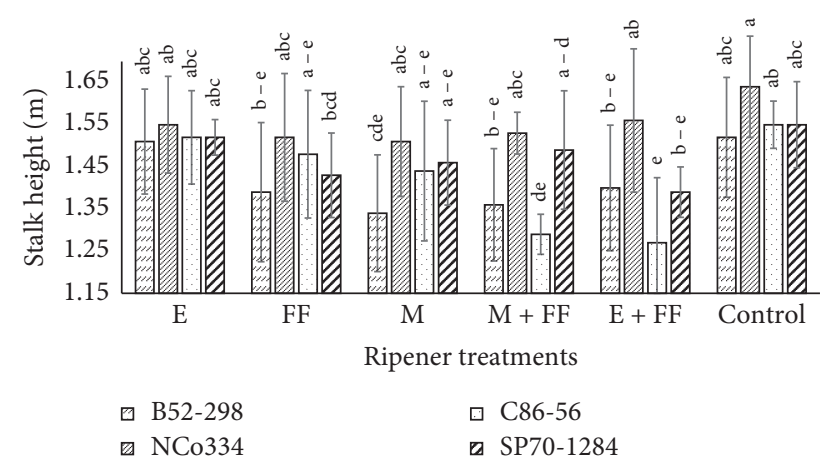

Figure 2: Difference in stalk height among sugarcane varieties for the ripeners Ethephon $^{\mathrm{TM}}(\mathrm{E})$, Fusilade Forte $(\mathrm{FF})$, Moddus ${ }^{\mathrm{TM}}(\mathrm{M})$, Moddus $^{\mathrm{TM}}+$ Fusilade Forte ${ }^{\mathrm{TM}}$ combination $(\mathrm{M}+\mathrm{FF})$, and Ethephon $^{\mathrm{TM}}+$ Fusilade Forte $^{\mathrm{TM}}$ combination $(\mathrm{E}+\mathrm{FF})$ treatments. Mean values followed by the same letter are not significantly different according to $\mathrm{HSD}_{0.05}$. The bars indicate the mean standard deviations of six observations.

reduction in stalk weight, relative to the control treatment, was relatively small. However, Ethephon ${ }^{\mathrm{TM}}$ was statistically at par with the control (unsprayed) treatment (Figure 3). The largest reduction in stalk weight was recorded in the Moddus $^{\mathrm{TM}}+$ Fusilade Forte ${ }^{\mathrm{TM}}$ combination treatment (8.36\%), while the lowest reduction in stalk weight was obtained from the Moddus ${ }^{\mathrm{TM}}$ treatment $(6.31 \%)$.

The reason for the relatively small reduction in stalk weight might have been due to varietal differences because not all varieties showed significant reductions in stalk height in response to ripener treatments (Figure 2). Additionally, the effective ripening (increase in sucrose mass per stalk), as indicated by the increase in sucrose concentration by the various ripener treatments (Figure 4), could also have partially counteracted the effects on stalk height (Figure 2).

3.1.3. Number of Millable Stalks. The number of millable stalks (stalk population) was not significantly affected by the ripener main effect as well as by its interactions (Tables 1 and Figure 3). Similar to the current result, Lu et al. [36] also demonstrated the negligible effect of 2-chloroethylophsphonic acid on stalk population. In contrast, Abo El-Hamd

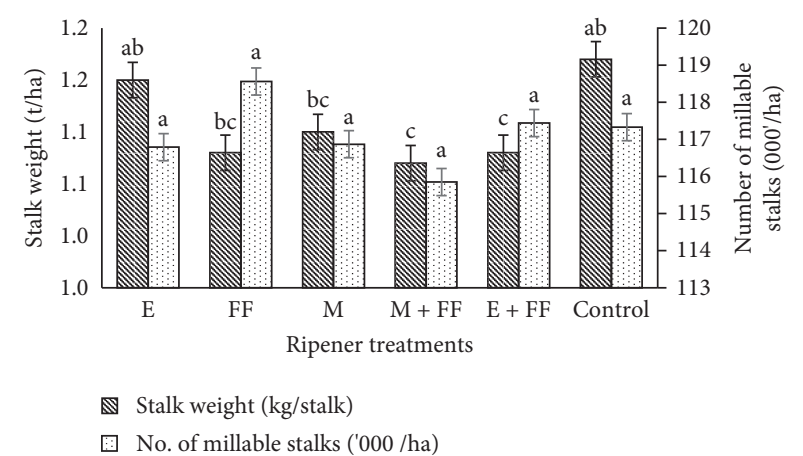

Figure 3: The effects of ripeners Ethephon ${ }^{\mathrm{TM}}$ (E), Fusilade Forte ${ }^{\mathrm{rm}}$ (FF), Moddus ${ }^{{ }^{\mathrm{TM}}}$ (M), Moddus ${ }^{\mathrm{TM}}+$ Fusilade Forte ${ }^{\mathrm{TM}}$ combination $(\mathrm{M}+\mathrm{FF})$, and Ethephon ${ }^{\mathrm{TM}}+$ Fusilade Forte $^{\mathrm{TM}}$ combination $(\mathrm{E}+\mathrm{FF})$ treatments on stalk weight and number of millable canes. Mean values followed by the same letter are not significantly different according to $\mathrm{HSD}_{0.05}$. The bars indicate the mean standard deviations of twenty-four observations.

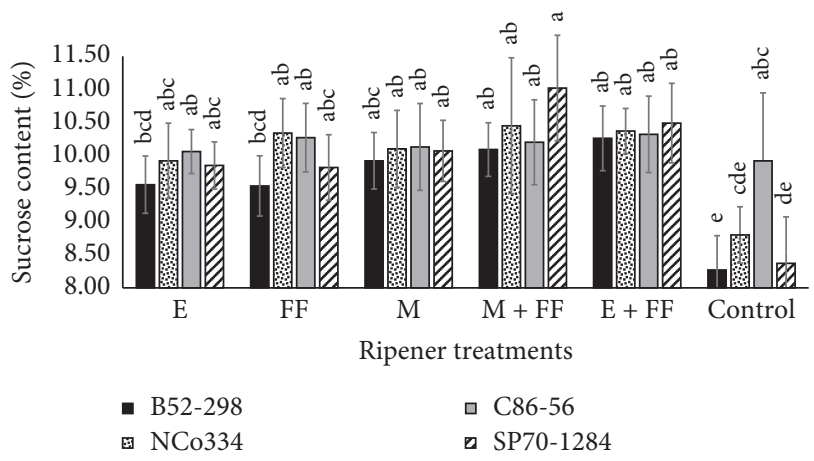

FIGURE 4: Difference in sucrose content among sugarcane varieties B52-298, NCo334, C86-56, and SP70-1284 for the ripeners Ethephon $^{\mathrm{TM}}$ (E), Fusilade Forte ${ }^{\mathrm{TM}}$ (FF), Moddus ${ }^{\mathrm{TM}}$ (M), Moddus $^{\mathrm{TM}}+$ Fusilade Forte $^{\mathrm{TM}}$ combination $(\mathrm{M}+\mathrm{FF})$, and Ethephon $^{\mathrm{TM}}+$ Fusilade Forte $^{\mathrm{TM}}$ combination $(\mathrm{E}+\mathrm{FF})$ treatments. Mean values followed by the same letter are not significantly different according to $\mathrm{HSD}_{0.05}$. The bars indicate the mean standard deviations of six observations.

et al. [35] reported a significant reduction in stalk population due to 2-chloroethylphosphonic acid applied at a higher rate (1143 $\mathrm{g}$ ai ha $\left.{ }^{-1}\right)$. Likewise, Abo El-Hamd et al. [35] also demonstrated that fluazifop-p-butyl at a higher rate $(88.3 \mathrm{~g}$ ai $\mathrm{ha}^{-1}$ ) had resulted in a significant reduction in stalk population. The combination of 2-chloroethylphosphonic acid $\left(1143 \mathrm{~g}\right.$ ai ha $\left.^{-1}\right)+$ fluazifop-p-butyl $\left(88 \mathrm{~g}\right.$ ai ha $\left.{ }^{-1}\right)$ also reduced stalk population [35].

\subsection{Cane Yield, Sucrose Content, and Sucrose Yield}

3.2.1. Cane Yield. The ripener treatments did not result in a significant reduction in cane yield (Table 2 and Figure 5). Therefore, cane yield did not reflect the observations of ripener treatment effects on stalk height and weight (Figures 2 and 3). The absence of significant effects on cane yield among the ripener treatments might have been due to effective ripening (increase in sucrose mass per stalk), as 
TABLE 2: Combined analysis of variance ( $p$ values) for cane yield, sucrose content, and sucrose yield in a field experiment involving four sugarcane varieties, six chemical ripener treatments, and two locations.

\begin{tabular}{lccc}
\hline Source of variation & $\begin{array}{c}\text { Cane yield } \\
\left(\mathrm{t} \mathrm{ha}^{-1}\right)\end{array}$ & $\begin{array}{c}\text { Sucrose } \\
\text { content }(\%)\end{array}$ & $\begin{array}{c}\text { Sucrose } \\
\text { yield }\left(\mathrm{t} \mathrm{ha}^{-1}\right)\end{array}$ \\
\hline Variety $(V)^{1}$ & 0.001 & 0.003 & 0.001 \\
Ripener $(R)^{2}$ & 0.201 & 0.001 & 0.003 \\
Location $(L)^{3}$ & 0.064 & 0.102 & 0.172 \\
$V \times R$ & 0.956 & 0.001 & 0.100 \\
$R \times L$ & 0.733 & 0.295 & 0.757 \\
$V \times R \times L$ & 0.995 & 0.999 & 0.998 \\
\hline
\end{tabular}

${ }^{1}$ Varieties: B52-298, NCo334, C86-56, and SP70-1284; ${ }^{2}$ Ripener treatments: Ethephon $^{\mathrm{TM}}$, Fusilade Forte ${ }^{\mathrm{TM}}$, Moddus ${ }^{\mathrm{TM}}$, Moddus ${ }^{\mathrm{Tm}}+$ Fusilade Forte $^{\mathrm{TMx}}$ combination, Ethephon ${ }^{\text {rx }}+$ Fusilade Forte ${ }^{\text {px }}$ combination, and control (unsprayed). ${ }^{3}$ Location: Wonji-Shoa and Metahara.

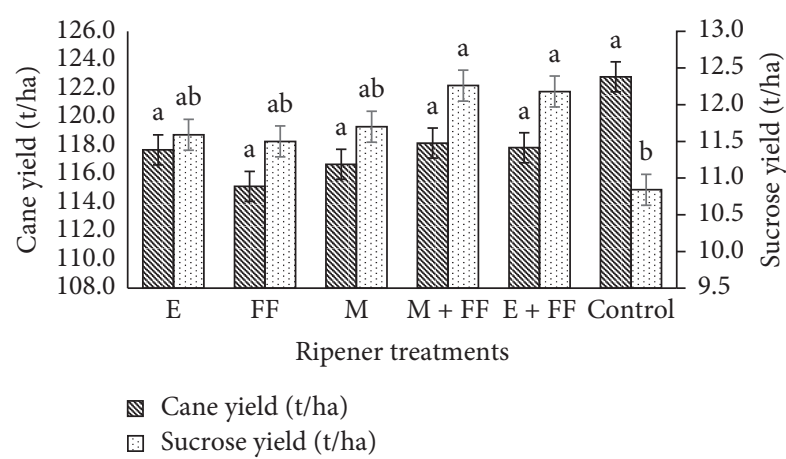

Figure 5: The effects of ripeners Ethephon ${ }^{\mathrm{TM}}$ (E), Fusilade Forte ${ }^{\mathrm{TM}}$ (FF), Moddus ${ }^{\mathrm{TM}}(\mathrm{M})$, Moddus ${ }^{\mathrm{TM}}+$ Fusilade Forte ${ }^{\mathrm{TM}}$ combination $(\mathrm{M}+\mathrm{FF})$, and Ethephon ${ }^{\mathrm{TM}}+$ Fusilade Forte $^{\mathrm{TM}}$ combination $(\mathrm{E}+\mathrm{FF})$ on cane and sucrose yield. Mean values followed by the same letter are not significantly different according to $\mathrm{HSD}_{0.05}$. The bars indicate the mean standard deviations of twenty-four observations.

indicated by the increase in sucrose content induced by the various ripener treatments (Figure 4), as well as the relatively shorter spray-to-harvest intervals [37] and lower rates used in this study [35].

Similar to the current results, different authors also reported the lack of significant cane yield reduction due to treatment with fluazifop-p-butyl [37] and trinexapac-ethyl [27, 28]. Contrarily, Abo El-Hamd et al. [35] reported a significant cane yield reduction due to treatment with fluazifop-p-butyl. Similarly, Orgeron [38] reported a significant reduction of cane yield due to treatment with trinexapac-ethyl applied at 300 and $350 \mathrm{~g}$ ai ha ${ }^{-1}$.

3.2.2. Sucrose Content. The sucrose content (\%) was highly significantly ( $p=0.001$ ) affected by the interaction of variety with ripeners (Table 2). The highest sucrose content (11.02\%) was obtained from the variety SP70-1284 sprayed with Moddus $^{\mathrm{Tm}}+$ Fusilade Forte $^{\mathrm{Tm}}$, while the lowest sucrose content was obtained from the variety B52-298 (8.27\%) with no spray (Figure 4). Except for variety C86-56, where none of the ripener treatments outperformed the control treatment, all the ripener treatments outperformed the control treatment in the case of varieties B52-298 and SP70-1284
(Figure 4). However, in the case of variety NCo334, all the treatments, except for the Ethephon ${ }^{\text {TM }}$ treatment, outperformed the control (Figure 4). The difference among the varieties in sucrose content response to the chemical ripeners could be due to their innate genetic variation. Earlier works also demonstrated the variation in response to chemical ripeners and that all varieties do not necessarily respond equally well to chemical ripeners [28, 39].

The effectiveness of Ethephon ${ }^{\text {nim }}$ in enhancing sucrose content is accredited to ethylene release [12]. The mechanism through which 2-chlorethylphosphonic acid increased sucrose content might be due to its potential to regulate sink strength due to its synergistic action with abscisic acid [40], which decreases the demand of sucrose for vegetative growth [24]. Fusilade Forte $^{\mathrm{TM}}$ increased sucrose content through the suppression of new tissue formation due to the interference with long-chain fatty acid synthesis in the stalk apical meristem [12]. On the other hand, Moddus ${ }^{\mathrm{TM}}$ increases sucrose content through the inhibition of internode elongation resulting from the reduction in the gibberellic acid $\left(\mathrm{GA}_{1}\right)$ levels [24].

Previous studies also demonstrated the effectiveness of 2-chloroethylphosphonic acid, fluazifop-p-butyl [33, 35], and trinexapac-ethyl [24] in enhancing the sucrose content of sugarcane. The effectiveness of the combination of 2chloroethylphosphonic acid + fluazifop-p-butyl in increasing sucrose content of sugarcane was also confirmed in previous studies [34, 37]. Similarly, van Heerden [37] confirmed the effectiveness of trinexapac-ethyl + fluazifopp-butyl in improving sucrose content.

3.2.3. Sucrose Yield. The ripener main effect was significant $(p=0.001)$ on sucrose yield $\left(\mathrm{t} \mathrm{ha}^{-1}\right)$; however, none of the interactions with ripeners were significant (Table 2). The ripener treatments Moddus ${ }^{\mathrm{TM}}+$ Fusilade Forte $^{\mathrm{Tm}}$ combination and Ethephon ${ }^{\mathrm{TM}}+$ Fusilade Forte $^{\mathrm{Tw}}$ combination resulted in the highest sucrose yields of 12.26 and $12.18 \mathrm{tha}^{-1}$, respectively, and were the only treatments that differed significantly from the control (unsprayed) treatment (Figure 5).

The significantly higher sucrose yield obtained from the Moddus $^{\mathrm{Tm}}+$ Fusilade Forte $^{\mathrm{Tm}}$ combination and Ethephon ${ }^{\mathrm{Tm}}+$ Fusilade Forte ${ }^{\mathrm{Tx}}$ combination treatments could be attributed to the significant increase in sucrose content that exceeded the other treatments (Figure 5) and the absence of any negative effect of these treatments on cane yield (Figure 4). In line with the current results, other studies $[33,35]$ also confirmed the sucrose yield improvement from the 2-chloroethyl-phosphonic acid and fluazifop-p-butyl combination treatment. van Heerden [41] also demonstrated that compared with the sole Ethephon ${ }^{\text {Tw }}$ and Fusilade Forte ${ }^{\mathrm{Tm}}$ treatments, the Ethephon ${ }^{\mathrm{TM}}+$ Fusilade Forte $^{\mathrm{TM}}$ and the Moddus ${ }^{\mathrm{TM}}+$ Fusilade Forte $^{\mathrm{TM}}$ combination treatments performed better in terms of sucrose yield increase.

3.3. Economic Analysis. A maximum net benefit of USD $6765.08 \mathrm{ha}^{-1}$ was obtained from the combination treatment of Moddus $^{\mathrm{TM}}+$ Fusilade Forte $^{\mathrm{TM}}$ followed by the combination treatment of Ethephon ${ }^{\mathrm{TM}}+$ Fusilade $^{\mathrm{T}}$ Forte $^{\mathrm{TM}}$ (USD $6733.83 \mathrm{ha}^{-1}$ ). The lowest field benefit of USD $6016.27 \mathrm{ha}^{-1}$ was obtained from the control treatment (Table 3 ). 
TABLE 3: Partial budget for sucrose yield improvement from the five ripener treatments compared with the experiment conducted at WonjiShoa and Metahara sugarcane plantations.

\begin{tabular}{|c|c|c|c|c|c|c|}
\hline \multirow[b]{2}{*}{ Parameters } & \multicolumn{6}{|c|}{ Ripener treatments } \\
\hline & $\begin{array}{c}\text { Control } \\
\text { (unsprayed) }\end{array}$ & Ethephon $^{\mathrm{rm}}(\mathrm{E})$ & Fusilade Forte $^{\mathrm{rm}}(\mathrm{FF})$ & $\operatorname{Moddus}^{\mathrm{TM}}(\mathrm{M})$ & $\mathrm{M}+\mathrm{FF}$ & $\mathrm{E}+\mathrm{FF}$ \\
\hline Actual sucrose yield $\left(\mathrm{kg} \mathrm{ha}^{-1}\right)$ & 10840.00 & 11590.00 & 11500.00 & 11700.00 & 12260.00 & 12180.00 \\
\hline Adjusted sucrose yield $\left(\mathrm{kg} \mathrm{ha}^{-1}\right)$ & 9756.00 & 10431.00 & 10350.00 & 10530.00 & 11034.00 & 10962.00 \\
\hline Sales revenue from sucrose (USD ha ${ }^{-1}$ ) & 6016.27 & 6432.53 & 6382.58 & 6493.58 & 6804.38 & 6759.98 \\
\hline Saving from HT $\left(\mathrm{USD} \mathrm{ha}^{-1}\right)^{1}$ & 0.00 & 23.04 & 34.56 & 27.59 & 20.88 & 22.37 \\
\hline Gross field benefit (USD ha ${ }^{-1}$ ) & 6016.27 & 6455.57 & 6417.14 & 6521.16 & 6825.26 & 6782.35 \\
\hline Cost of chemicals (USD ha-1) & 0.00 & 45.00 & 3.93 & 33.33 & 48.93 & 37.27 \\
\hline Cost of spraying (USD ha ${ }^{-1}$ ) & 0.00 & 5.63 & 5.63 & 5.63 & 11.25 & 11.25 \\
\hline Cost of ripening (costs that vary) (USD ha $\mathrm{ha}^{-1}$ ) & 0.00 & 50.63 & 9.56 & 38.96 & 60.18 & 48.52 \\
\hline Net benefit (USD ha ${ }^{-1}$ ) & 6016.27 & 6404.94 & 6407.58 & 6482.21 & 6765.08 & 6733.83 \\
\hline Marginal rate of return & - & 7.68 & 40.94 & 11.96 & 12.44 & 14.79 \\
\hline Return on investment (residuals) $\left(\mathrm{USD} \mathrm{ha}^{-1}\right)$ & 6016.27 & 6354.32 & 6398.02 & 6443.25 & 6704.90 & 6685.31 \\
\hline
\end{tabular}

${ }^{1} \mathrm{HT}=$ harvest and transport.

The highest marginal rate of return of $4094 \%$ was obtained from the Fusilade Forte ${ }^{\mathrm{Tm}}$ sole treatment followed by the Ethephon ${ }^{\mathrm{TM}}+$ Fusilade Forte $^{\mathrm{Tx}}$ combination (1479\%), Moddus $^{\text {The }}$ (1196\%), and Ethephon ${ }^{\text {ix }}$ (768\%). The highest marginal rate of return in the sole Fusilade Forte ${ }^{\mathrm{Tm}}$ treatment was due to the deflated cost of ripening (the chemical and its spraying costs) (Table 3 ). Since net field benefit and marginal rate of return are not a final criterion for recommendation of the best ripener treatment as they do not account for returns on investment (residuals), returns on investment were also calculated (Table 3). The maximum returns on investment was obtained from the Moddus ${ }^{\mathrm{TM}}+$ Fusilade Forte $^{\mathrm{TM}}$ combination treatment (USD $6704.90 \mathrm{ha}^{-1}$ ).

Therefore, the most economical option was derived from the Moddus ${ }^{\mathrm{TM}}+$ Fusilade Forte ${ }^{\mathrm{TM}}$ combination treatment with a marginal rate of return of $1244 \%$ (Table 3 ). In general, the marginal rate of returns obtained in all the ripener treatments compared with the control (unsprayed) treatment were greater than 1 (Table 3), which is above the minimum value (50\%) assumed.

\section{Conclusions}

The results of this study showed that the two combination ripener treatments led to a considerable increase in sucrose yield of the sugarcane varieties B52-298, NCo334, and SP701284 at Wonji-Shoa and Metahara sugarcane plantations. The study also illustrated the influence of ripeners on stalk height and weight in some treatments and varieties, although these effects did not translate in significant effects on cane yield. It was also noted that ripener treatments did not influence stalk diameter, number of internodes, and stalk population. The superior increase in sucrose yield in the two combinations of ripener treatments was primarily attributed to the significant increase in sucrose content. However, in economic terms, the Moddus ${ }^{\mathrm{Tm}}+$ Fusilade Forte $^{\mathrm{Tm}}$ combination treatment was found to be the best option. Therefore, it is recommended that these sugarcane plantations should verify this experimental result at a commercial scale in the early crushing season on immature crops.

\section{Data Availability}

The data used to support the study were obtained from Ethiopian Sugar Research Main Center.

\section{Conflicts of Interest}

The authors declare that they have no conflicts of interest.

\section{Acknowledgments}

The authors thank the Ethiopian Sugar Corporation for funding this research work and the management and technical team staff of Wonji-Shoa and Metahara Research Stations for their collaboration and provision of assistance in every aspect.

\section{References}

[1] Ethiopian Investment Agency (EIA), Investment Opportunity Profile for Sugarcane Plantation and Processing in Ethiopia, Ethiopian Investment Agency, Addis Ababa, Ethiopia, 2012, http://ethemb.se/wp-content/uploads/2013/ 07/Sugar-Cane-Plantation-and-Processing-in-Ethiopia.pdf.

[2] E. Tena, F. Mekbib, and A. Ayana, "Sugarcane landraces of Ethiopia: germplasm collection and analysis of regional diversity and distribution," Advances in Agriculture, vol. 201418 pages, 2018.

[3] B. Bharati, R. Panta, and K. Khanal, "Assessing socio-economic condition of sugarcane producers in Nawalparasi district of Western Nepal," Biomedical Journal of Scientific \& Technical Research, vol. 12, no. 3, pp. 9296-9297, 2018.

[4] LMC International Global, Regional and Domestic Sugar Markets, Implications for Ethiopian Industry, LMC International Global, Oxford, UK, 2019, https://addisstandard.com/ wp-content/uploads/2019/11/Global-Regional-and-DomesticSugar-Markets-LMC.pdf.

[5] USDA, Global Agricultural Information Network, "Assessments of commodity and trade issues made by USDA staff and not necessarily statements of official US Government Policy," Gain Report Number ET 1903, Washington, NY, USA, USDA, http://agriexchange.apeda.gov.in/MarketReport/Reports/ Ethiopia_in_the_Market_to_Buy_200000_Metric_Tons_of_ Sugar_Addis_Ababa_Ethiopia_2-21-2019.pdf, 2019. 
[6] J. Hodbod, J. Tomei, and T. Blaber-Wegg, "Comparative analysis of the equity outcomes in three sugarcane-ethanol systems," Journal of Environment \& Development, vol. 24, no. 20, pp. 211-236, 2015.

[7] T. E. Morgan, "Effects of ripeners on early season sugar production in sugar cane," Research Thesis, James Cook University, Townsville, Australia, 2003.

[8] N. Ayele, T. Samuel, N. Tadesse et al., "Challenges of ripening of sugarcane at tendaho, Metahara and wonji-shoa sugar estates," European Journal of Food Science and Technology, vol. 4, no. 4, pp. 22-30, 2016.

[9] M. K. Ebrahim, O. Zingsheim, M. N. El-Shourbagy, P. H. Moore, and E. Komor, "Growth and sugar storage in sugarcane grown at temperatures below and above optimum," Journal of Plant Physiology, vol. 153, no. 5-6, pp. 593-602, 1998.

[10] M. A. Silva and M. M. Caputo, "Ripening and the use of ripeners for better sugarcane management," in Crop Management: Cases and Tools for Higher Yield and Sustainability, F. R. Marin, Ed., pp. 2-24, Rijeka, Croatia, 2012.

[11] N. G. Inman-Bamber, "Factors affecting dry matter and sucrose content of sugarcane," Proceedings of South African Sugar Technologists Association, vol. 70, pp. 36-37, 1996, https://sasta.co.za/download/8/1990-1999/2821/1996_ inman_factors-affecting-dry-matter.pdf.

[12] P. D. R. van Heerden, E. Eggleston, and R. A. Donaldson, "Ripening and post-harvest deterioration," in Sugarcane Physiology, Biochemistry and Functional Biology, F. C. Botha and P. H. Moore, Eds., pp. 55-84, John Wiley \& Sons, Inc. Iowa, Hoboken, NJ, USA, 1st edition, 2014.

[13] F. Yirefu, Y. Zekarias, and L. Mengistu, Handbook of Sugarcane Pest Management in Ethiopia, Ethiopian Sugar Development Agency, Wonji, Ethiopia, 2009, https:// www.researchgate.net/publication/285026017_Handbook_ for_sugarcane_pest_management_in_Ethiopia.

[14] N. P. Cardozo and P. C. Sentelhas, "Climatic effects on sugarcane ripening under the influence of cultivars and crop age," Scientia Agricola, vol. 70, no. 6, pp. 449-456, 2013.

[15] G. D. Bonnet, M. L. Hewitt, and D. Glassop, "Effects of high temperature on the growth and composition of sugarcane internodes," Australian Journal of Agricultural Research, vol. 57, pp. 1087-1095, 2006.

[16] A. Singles, A. J. Kennedy, and C. N. Bezuidenhout, "The effect of water stress on sugarcane biomass accumulation and partitioning," Proceedings of South African Sugar Technologists Association, vol. 74, pp. 169-172, 2000.

[17] A. Getaneh and T. Negi, "Effect of length of pre-harvest drying-off period during the cool season on soil moisture content and cane quality of sugarcane cultivars at Metahara Sugar Estates," African Journal of Agronomy, vol. 2, no. 9, pp. 211-218, 2014, http://www.internationalscholarsjournals. org.

[18] J. M. Gosnell and J. E. Lonsdale, "Some effects of drying off before harvest on cane and yield quality," Proceedings of International Society of Sugar Cane Technologists, vol. 15, pp. 701-711, 1974, http://www.issct.org/proceedings/1974. html.

[19] P. D. R. van Heerden, T. P. Mbatha, and S. Ngxaliwe, "Chemical ripening of sugarcane with trinexapac-ethyl (Moddus) - mode of action and comparative efficacy," Field Crops Research, vol. 181, pp. 69-75, 2015.

[20] M. J. Robertson, R. C. Muchow, R. A. Donaldson, N. G. Inman-Bamber, and A. W. Wood, "Estimating the risk associated with drying-off strategies for irrigated sugarcane before harvest," Australian Journal of Agricultural Research, vol. 50, no. 1, pp. 65-77, 1999.

[21] C. D. Dalley and E. P. Richard, "Herbicides as ripeners for sugarcane," Weed Science, vol. 58, no. 3, pp. 329-333, 2010.

[22] V. T. Banasihan, V. V. Macalaguim, and T. C. Mendoza, "Glyphosate as a ripener in sugarcane production in Batangas," Philippine Journal of Crop Science, vol. 32, no. 3, pp. 31-45, 2007.

[23] T. Morgan, P. Jackson, L. McDonald, and J. Holtum, "Chemical ripeners increase early season sugar content in a range of sugarcane varieties," Australian Journal of Agricultural Research, vol. 58, no. 3, pp. 233-241, 2007.

[24] D. Eastwood and H. D. Davis, "Chemical ripening in Guyanaprogress and prospects,” Sugar Cane, vol. 3, pp. 4-17, 1997.

[25] H. Jaramillo, F. Schuitemaker, and C. Garcia, "Ripening sugarcane with Ethrel $^{\mathrm{TM}}$ plant growth regulator in Colombia," Proceedings of International Society of Sugar Cane Technologists, vol. 16, pp. 1931-1935, 1977.

[26] S. F. Yang, "Ethylene evolution from 2-chloroethylphosphonic acid," Plant Physiology, vol. 44, no. 8, pp. 1203-1204, 1969.

[27] P. A. P. Resende, J. E. Soares, and M. Hudetz, "Moddus, a plant growth regulator and management tool for sugarcane in Brazil," International Sugar Journal, vol. 102, pp. 5-9, 2000, https://www.cabdirect.org/cabdirect/abstract/20016785792.

[28] G. Kingston and C. M. Rixon, "Ripening responses of twelve sugarcane cultivars to Moddus (trinexapac-ethyl)," Proceedings of Australian Society of Sugar Cane Technologists, vol. 29, pp. 328-338, 2007, https://www. researchgate.net/publication/291292726_Ripening_responses_ of_twelve_sugarcane_cultivars_to_ModdusR_trinexapac-ethyl.

[29] APECS (Agrima Project Engineering and Consultancy Services), "Ethiopian sugar corporation," Agricultural Research Services, APECS, Main Report Part II, Bombay, India, 1987.

[30] V. Berg, "Control of the cane sugar manufacture," Manual for Sugar Chemist Course of H.V.A, Wonji-Shoa Sugar Factory, Addis Ababa, Ethiopia, 1972.

[31] SAS institute, The Statistical Analysis Software System for Windows, Version 9.2, SAS institute INC., Cary NC, USA, 2009.

[32] CIMMYT, From Agronomic Data to Farmer Recommendations: An Economics Training Manual Completely Revised Edition, DF, Mexico City, Mexico, 1988.

[33] P. D. R. Van Heerden, "Response of selected South African coastal sugarcane varieties to chemical ripeners: active ingredient effectiveness and associated impacts on grower and miller sustainability," Proceedings of South African Sugar Technologists Association, vol. 92, pp. 18-21, 2019.

[34] H. Rostron, "Chemical ripening of sugarcane with fusilade super," Proceedings of South African Sugar Technologists Association, vol. 59, pp. 168-175, 1985.

[35] A. S. Abo El-Hamd, M. A. Bakheet, and A. F. I. Gadalla, "Effect of chemical ripeners on juice quality, yield and yield components of some sugarcane varieties under the conditions of Sohag Governorate," American-eurasian Journal of Agriculture \& Environmental Science, vol. 13, no. 11, p. 1458, 2013.

[36] J. Lu, L. Zha, X. Li, J. Fang, and W. Zhuang, "A study on the application and residues of plant growth regulators in the fruit sugarcane grown in the sub-suitable region," Journal of Agricultural Sciences, vol. 2, no. 4, pp. 254-256, 2010.

[37] P. D. R. van Heerden, "Evaluation of Trinexapac-ethyl (Moddus) as a new chemical ripener for the South African 
sugarcane industry," Sugar Tech, vol. 16, no. 3, pp. 295-299, 2013.

[38] A. J. Orgeron, "Sugarcane growth, sucrose content, and yield response to the ripeners glyphosate and trinexapac-ethyl," LSU Doctoral Dissertations, vol. 1362, 2012, https:// digitalcommons.lsu.edu/gradschool_dissertations/1362.

[39] H. Rostron, "The response of sugarcane varieties to chemical ripeners in the Natal Midlands," Proceedings of South African Sugar Technologists Association, vol. 63, pp. 164-166, 1989.

[40] C. P. Cunha, G. G. Roberto, R. Vicentini et al., "Ethyleneinduced transcriptional and hormonal responses at the onset of sugarcane ripening," Scientific Reports, vol. 7, no. 1, p. 43364, 2017.

[41] P. D. R. van Heerden, "Evaluation of Moddus ${ }^{\mathrm{TM}}$ as a new chemical ripener for the South African sugar industry: preliminary findings," Proceedings of South African Sugar Technologists Association, vol. 85, pp. 193-195, 2012. 